\title{
Self-Regulated Learning and Future Orientation on Career in SMART Ekselensia Students
}

\author{
Galih Nur Ardiansyah ${ }^{1}$, Nur Fajriati Nadlifatil Khoir,"*
}

\author{
${ }^{I}$ Teacher of SMART Ekselensia Indonnesia, Dompet Dhuafa Pendidikan, Indonesia \\ ${ }^{2}$ Staff Research and Development, Dompet Dhuafa Pendidikan, Indonesia \\ ${ }^{*}$ Corresponding author. Email: nur.fajriati@dompetdhuafa.org
}

\begin{abstract}
The main objective of the present study has been to examine the Self-Regulated Learning and Future Orientation in senior high school students of SMART Ekselensia Indonesia. The research was conducted using quantitative methods with a descriptive approach. There are 170 SMART high school students in the age of boy adolescents from marginal families. From the results of this study, it is known that most SMART Ekselensia students have a high SRL level (93.5\%) and a mature Future Orientation (95.88\%). The highest SRL stages are self-reflection (99.37\%), forethought $(98.74 \%)$, and performance (90.57\%). Meanwhile, FO has a descriptive average in motivation (96.47\%), cognitive representation $(75.29 \%)$, and behavior $(83.53 \%)$. External factors such as family background play an important role. Meanwhile, a low score was obtained due to a lack of internal motivation.
\end{abstract}

Keywords: career, future orientation, self-regulated learning, senior high school

\section{BACKGROUND}

The explanation of education has been formulated in the UU No. 20 Tahun 2003. Education is a conscious and planned effort to create a learning atmosphere and learning process so that students actively develop their potential to have religious, spiritual strength, self-control, personality, intelligence, noble character, and skills needed by themselves, society, nation, and state (Perpusnas, 2019). In practice, education in Indonesia is divided into three levels, namely primary education, secondary education, and higher education (Perpusnas, 2019) which each of these levels has its own implementation goals. Secondary education is expected to provide an overview of how the future will be in the career world and be more independent in facing the future. Furthermore, higher education is an improvement in equipping students with abilities that can support career success from the professions desired by students in the future.

Determining one's future is one that is discussed in the aspect of developmental tasks. Havighurst (1972) said that one of the developmental tasks in adolescents aged 13-18 years is to determine career preparation. Teachers and education providers should direct and guide their students in determining their future, especially in the career field. Future orientation in the career field tries to describe the process from planning for the future of the career field to the extent to which the individual has made efforts to achieve the career he wants. Adolescence, represented by high school students, is crucial in determining their future orientation (Eldeleklioglu, 2012). The mindset of teenagers who have started to abstract can explore and appreciate how the picture of their life will be (Santrock, 2013). It underlines the importance of knowledge and ability in determining future orientation, especially in the career field among teenagers. On the other hand, adolescents at the identity moratorium or identity diffusion stage tend to struggle in making decisions and work plans (Santrock, 2013). Based on the stage of identity status formation, adolescents who have formed their identity will be better at determining job choices to goals, both long term and short term.

SMART Ekselensia Indonesia is a boarding school. The students live in the dormitory and integrate all learning at school with students' daily lives. The impact of this school system is the number of activities that students must carry out. Ideally, the students need to regulate their behavior, manage time, and regulate their learning activities. Data obtained from final year students of SMART Ekselensia Indonesia, almost all students are still in the dilemma stage in determining majors. It can be seen from the number of counseling majors conducted by Guidance and Counseling regarding the majors of interest in higher education. Some students stated that they did not have any aspirations for what they would be in the future. Most students often experience delays in entering class, delays in collecting assignments, and sometimes students are found absent during the lesson. Their grades tend to decrease from the first semester to the final semester.

Individual success to achieve achievement in school is determined by how each individual performs in class. Ideally, the achievements obtained by each individual are derived from how individuals determine learning goals, regulate their behavior, manage time, and regulate their learning activities, as well as evaluate what has been done to achieve predetermined goals so that they can optimize absorption of materials that enable them to excel in their fields. SelfRegulated Learning (SRL) is a form of a directive process carried out by individuals to evaluate what has been done to achieve its goals (Zimmerman, 1989). Self-Regulated 
Learning itself is described in three phases (Zimmerman \& Moylan, 2009). The first phase is forethought which process is at the beginning before the learning process occurs. It refers to self-motivation and willingness to carry out the learning process. The second phase is performance, which is the learning activity itself. The third phase is self-reflection, which is a reaction and evaluation result of the learning activities.

However, in reality, the phenomenon in SMART Ekselensia Indonesia students is inversely proportional, so there is a need for a deeper review to find the factors causing the alleged low Self-Regulated Learning in students at the school. So, researchers tried to find out from the two psychological aspects: Future Orientation and Self-Regulated Learning, of students. So that the student profiles of these two aspects can be known, appropriate interventions could be determined so that the school's goals and vision for graduating students with superior characteristics and high competitiveness can be realized.

The purpose of this study was to obtain empirical data regarding the profile picture of Self-Regulated Learning and Future Orientation of SMART Ekselensia Indonesia students as initial data and the basis for making interventions and classroom actions for Guidance and Counseling Services. So, teachers can intervene and optimize these two aspects to help the school's goals and vision.

\section{METHODS}

The design of this research is non-experimental quantitative research with a descriptive approach. Nonexperimental quantitative research is defined as nonexperimental quantitative research because there is no manipulation of an independent variable (Christensen, Johnson, and Turner, 2015). In short, quantitative nonexperimental research is defined as a research design in which the researcher does not manipulate any independent variables studied in the study. Then this research using the descriptive method. One of the definitions of descriptive research method is the descriptive type of research. The goal is to provide an accurate description or picture of a particular situation or phenomenon (Christensen, Johnson and Turner, 2011).

Self-Regulated Learning is defined as self-regulated thoughts, feelings, and behaviors planned and cyclically adapted based on performance feedback to attain self-set goals (Zimmerman, 1989). Future Orientation is a person's goal in life and the way of accomplishing it. Future orientation can also be interpreted as a way of life and everything they should approach or avoid (Seginer R. , 2009). The Self-Regulated Learning measuring instrument was compiled by Syahputri (2017) which was obtained based on the self-regulated learning phase according to Zimmerman and Moylan (2009). This phase consists of forethought, performance, and self-reflection. In each phase, there is a significant category and a form of major category in it. Meanwhile, the measuring instrument for future orientation in the career field was obtained through a questionnaire adapted from the Prospective Life Course Questionnaire by (Seginer R. , 2009) which was adapted to the conditions of the research subject.
The research instrument has gone through the verification stage. If calculated using Cronbach Alpha, the reliability is 0.9 for OF and 0.93 for SRL. The research subjects were SMART Ekselensia students as many as 170 people aged 1118. The implementation of this research is to start in 2020 in the SMART Ekselensia Indonesia School environment.

\section{RESULTS}

\subsection{Future Orientation}

The following is a description of the Future Orientation of the career fields of SMART Ekselensia Indonesia students as a result of filling out the questionnaire:

Table 1. Future Orientation

Freque Percentage Mean
ncy

\begin{tabular}{|c|c|c|c|}
\hline Matured & 163 & $95,88 \%$ & 154,45 \\
\hline Immatured & 7 & $4,12 \%$ & (SD \\
\hline TOTAL & 170 & $100 \%$ & $17,071)$ \\
\hline
\end{tabular}

The table above shows that as many as $95.88 \%$ of SMART Ekselensia Indonesia students have a future orientation in a mature career field. Meanwhile, another $4.12 \%$ have an immature future orientation in the career field. The mean score of future orientation in the career field is 154.45 with $\mathrm{SD}=17,071$. It means, overall, SMART Ekselensia Indonesia students have a future orientation in a mature career field.

It is also analyzed the average description of the future orientation components of the career field owned by SMART Ekselensia Indonesia students is outlined in the following table:

Table 2. Average Score of Motivation

\begin{tabular}{|c|c|c|c|}
\hline $\begin{array}{l}\text { Motivatio } \\
\text { n }\end{array}$ & $\begin{array}{l}\text { Freque } \\
\text { ncy }\end{array}$ & $\begin{array}{l}\text { Percenta } \\
\text { ge }\end{array}$ & $\begin{array}{l}\text { Averag } \\
\text { e Score }\end{array}$ \\
\hline High & 164 & $96,47 \%$ & 84,08 \\
\hline Low & 6 & $3,53 \%$ & \multirow{2}{*}{$\begin{array}{l}(\mathrm{SD}= \\
9,24)\end{array}$} \\
\hline TOTAL & 170 & $100 \%$ & \\
\hline
\end{tabular}

The table above is a description of the Future Orientation of the career fields of SMART Ekselensia Indonesia students based on their constituent aspects. Viewed from the aspect of motivation, as many as $96.47 \%$ of respondents SMART Ekselensia Indonesia students have high motivation with an average of $84.08(\mathrm{SD}=9.24)$, while the other $3.53 \%$ have low motivation. Overall, this means that SMART Ekselensia Indonesia students have high motivation related to Future Orientation in the career field.

Table 3. Average Score of Cognitive Representation

\begin{tabular}{llll}
\hline Cognitive & Frequ & Percenta & Avera \\
Representat & ency & ge & ge \\
ion & & &
\end{tabular}




\begin{tabular}{|c|c|c|c|}
\hline Clear & 128 & $75,29 \%$ & 27.29 \\
\hline Unclear & 42 & $24,71 \%$ & \multirow{2}{*}{$\begin{array}{l}(\mathrm{SD}= \\
4,44)\end{array}$} \\
\hline TOTAL & 170 & $100 \%$ & \\
\hline
\end{tabular}

Furthermore, in the aspect of cognitive representation, as many as $75.29 \%$ of respondents of SMART Ekselensia Indonesia students have a clear cognitive representation regarding the Future Orientation of the career field. In contrast, the remaining $24.71 \%$ have unclear cognitive representations. It means that most of the SMART Ekselensia Indonesia students have a clear view or knowledge regarding the Future Orientation of the career field.

Table 4. Average Score of Behavior

\begin{tabular}{lccl} 
Behavior & $\begin{array}{l}\text { Frequ } \\
\text { ency }\end{array}$ & $\begin{array}{l}\text { Percenta } \\
\text { ge }\end{array}$ & $\begin{array}{l}\text { Avera } \\
\text { ge }\end{array}$ \\
\cline { 1 - 3 } $\begin{array}{l}\text { Frequentl } \\
\mathbf{y}\end{array}$ & 142 & $83,53 \%$ & \\
\cline { 1 - 3 } $\begin{array}{l}\text { Infrequen } \\
\text { tly }\end{array}$ & 28 & $16,47 \%$ & $\begin{array}{l}(\mathrm{SD}= \\
6,67)\end{array}$ \\
\cline { 1 - 2 } TOTAL & 170 & $100 \%$ & \\
\hline
\end{tabular}

Then on the behavioral aspect, as many as $83.53 \%$ of respondents from SMART Ekselensia Indonesia often show behaviors that can support them in achieving their goals or Future Orientation in their career fields, while as many as $16.47 \%$ others still rarely show behaviors that can support them in their careers. Achieve goals or Future Orientation career field.

In addition to the data above, we also classify the conditions of the Future Orientation in students' career fields into mature and immature categories according to their constituent aspects. It is intended to obtain detailed data from the measured Future Orientation conditions.

\subsection{Self-Regulated Learning}

The following is a description of the Self Regulated Learning of SMART Ekselensia Indonesia students as a result of filling out the questionnaire:

Table 5. Self-Regulated Learning

\begin{tabular}{cccc}
\hline SRL & $\begin{array}{c}\text { Freque } \\
\text { ncy }\end{array}$ & Percentage & Average \\
\cline { 1 - 3 } High & 159 & $93,5 \%$ & 273,39 \\
\cline { 1 - 3 } Low & 11 & $6,5 \%$ & $(\mathrm{SD}=$ \\
TOTAL & 170 & $100 \%$ & \\
\hline
\end{tabular}

Based on the table above, from 170 respondents, it is known that the level of Self-Regulated Learning in SMART Ekselensia Indonesia students is more in the high category, namely with a percentage of $93.5 \%$. In contrast, the remaining $6.5 \%$ has a level of Self-Regulated Learning that is relatively high. It means that most respondents tend to be responsible for the learning process of mathematics, consider learning mathematics as a proactive process, and are motivated and use strategies that enable respondents to achieve the desired academic results of mathematics.

Furthermore, the results of the description of Self Regulated Learning in students with low and high categories are also presented with the constituent aspects as follows:

Table 6. High Score of Self-Regulated Learning

High SRL

\begin{tabular}{cccc} 
SRL Phase & \multicolumn{2}{c}{ High } & Low \\
\cline { 2 - 4 } & F & $\%$ & F \\
\hline Forethought & 157 & $98,74 \%$ & 2 \\
\hline Performance & 144 & $90,57 \%$ & 15 \\
\hline $\begin{array}{c}\text { Self- } \\
\text { Reflection }\end{array}$ & 158 & $99,37 \%$ & 1 \\
\hline
\end{tabular}

Based on the table above, it is known that the distribution of the three phases in most of the high SRL respondents is with high self-reflection sequence $(99.37 \%)$, high forethought $(98.74 \%)$, and high performance $(90.57 \%)$. It indicates that these three phases tend to be implemented by the SMART Ekselensia Indonesia students who have high SRL scores.

Table 7. Low Score of Self-Regulated Learning

\begin{tabular}{cccccc}
\hline & \multicolumn{5}{c}{ Low SRL } \\
SRL & \multicolumn{3}{c}{ High } & \multicolumn{1}{c}{ Low } \\
\cline { 2 - 6 } & \% & F & $\%$ & F & $\%$ \\
\cline { 2 - 6 } & 1,26 & 2 & 18,18 & 9 & 81,82 \\
\hline $\begin{array}{c}\text { Forethou } \\
\text { ght }\end{array}$ & & & & & \\
\hline $\begin{array}{c}\text { Performa } \\
\text { nce }\end{array}$ & 9,43 & 0 & 0 & 11 & 100 \\
\hline $\begin{array}{c}\text { Self- } \\
\text { Reflectio } \\
n\end{array}$ & 0,63 & 8 & 72,73 & 3 & 27,27 \\
\hline
\end{tabular}

The data also shows that the distribution of the three phases in respondents with low Self-Regulated Learning is high self-reflection (72.73\%), and low forethought (18.18\%), and performance $(0 \%)$. It means that for student respondents with low SRL scores, it was found that the forethought and performance phases still tended to be less implemented. In contrast, the self-reflection phase tended to have been implemented in learning at SMART Ekselensia Indonesia.

\section{DISCUSSION}

The results are shown in the Future Orientation (FO) career field, show that most of the respondents of SMART Ekselensia Indonesia students have the OF category in the career field, which is considered mature (95.88\%). Ideally, the respondent has a well-arranged career plan, both in terms of motivation, knowledge related to his future career and how the behavior is displayed to achieve his future. However, based on the results of career counseling in schools, there are still many students who do not know for sure what their plans 
are, especially in the career field, which is reflected in choosing majors in higher education.

Several factors are thought to influence the discrepancy between the study results and the factual conditions in the field. The aspect of motivation shows that most of the respondents have high motivation when asked questions about their future. This motivation relates to the goals and interests of students in the future. These goals are formed through the stages of motivation and values (Ayesha, 2016). Three variables can describe OF with this motivational aspect, namely values relating to how individuals see their future, expectations related to individual self-confidence about the realization of expectations that are under specific fields, expectations, goals and planning, and internal control, which is a realization of the plan accompanied by a positive influence on the issues of the related field.

As already mentioned, SMART Ekselensia Indonesia students come from marginal groups with low social and economic profiles. It has become one of the triggers for these students to have a strong will and determination to change their families' fate and economic line. It is thought to be the basis of their motivation belonging to the high category.

Furthermore, from the aspect of cognitive representation related to content (the domain of life described by the individual) and valence (assumptions linking the future with what will be achieved and what will be avoided) have a reasonably good score (75.29\% are in a clear category). From the results of career counseling, it was found that although students have clear plans and desires, in reality, they do not fully understand the practical implementation of the understanding they already have, so this is suspected to be the cause of students who have low cognitive representation scores which have an impact on their OF category becomes immature.

The cognitive representation factors above also have an impact on the behavior they display to achieve their future. The existence of exploration power that all students have not carried out and the commitment that is still not fully formed is one of the factors that SMART Ekselensia Indonesia students do not have a mature plan regarding the career preparations they will achieve in the future. The aspect of commitment that is still not unanimous is also related to how the stages of their development are still searching for identity. External influences are still dominant in determining their direction and interests.

Speaking of external factors, one of the factors that influence OF in this career field is family. According to (Seginer R. , 2003), there are three ways in which family influences future orientation. One of them relates to the level of education of parents and socioeconomic status. Adolescents who come from families with high socioeconomic status tend to think about careers far ahead (Nurmi, 1991). It is under the condition of SMART Ekselensia Indonesia students, who all come from marginal family profiles.

The results also show that $93.5 \%$ of respondents have high SRL levels. High SRLs are dispersed into phases; high selfreflection $(99.37 \%)$, high forethought $(98.74 \%)$, and high performance $(90.57 \%)$. SRL has three stages, forethought, performance, and self-reflection. The high self-reflection score shows that SMART Ekselensia Indonesia students can perform self-judgment and self-evaluation well. The ability in the self-reflection process involves reflection and assessment from both the learner's self (internal factor) and the teacher (external factor).

SMART Ekselensia Indonesia is a boarding school where teachers and coaches monitor students' progress 24 hours a day. In addition, SMART Ekselensia Indonesia also has various programs and rules to ensure students can meet learning targets. The existence of rules and monitoring student learning outcomes regularly are factors that cause the self-reflection phase to achieve the highest score. It is proven that students with low SRL levels also have high selfreflection scores $(72.73 \%)$, although the other two phases have low scores; forethought $(18.18 \%)$ and performance $(0 \%)$.

Then, the next phase is the forethought phase. target setting, SMART Ekselensia Indonesia's supervisors and teachers direct their students to continue their education up to university. Higher education will open many opportunities for students' future, such as job opportunities, self-development, competitive attitude, et cetera. It is hoped that students will become people who can improve their families' living standards in the future.

Meanwhile, the performance phase includes self-control and self-observation expectations, task values, interests, and goal orientation (Panadero \& Alonso-Tapia, 2014). In the self-control category, students can carry out self-instruction, imagery and make learning strategies to achieve learning goals. In this stage, students are expected to use learning strategies such as clearly understanding goals, self-directed orders, imagery, time management, structured learning environment, help-seeking, incentives to enhance or maintain their interest, self consequences, et cetera. In this case, student performance still needs to be improved. Because all students have low scores in this phase. Students with a high SRL level have a performance score of $90.57 \%$, while students with a low SRL have a performance score of $0 \%$. Students need to be given direction regarding how to execute the learning process. The teacher's role as a mentor is needed to help students improve their performance in learning activities.

If seen as a cycle, motivation and performance are closely related. Students indicate this with low SRL levels who also have low forethought scores and low-performance scores. Students' inability to plan, such as determining goal setting and strategic planning, and lack of self-motivation beliefs such as self-efficacy, outcome expectations, task values, interests, and goal orientation, will affect performance in learning. So, students must increase their internal motivation. Internal motivation can come from long-term goals to be achieved in the future. In this study, most students have a future orientation in a mature career field, but the cognitive and behavioral representation factors still need improvement. Therefore, students need stimuli such as applying strategies in learning, practical implementation towards future career orientation, knowledge of future careers, and commitment to undergo the process. 


\section{CONCLUSION}

SMART Ekselensia Indonesia students in general already have high SRL and OF levels. However, the descriptive analysis method analysis shows that SMART Ekselensia Indonesia students still need assistance to improve some parts of the SRL and OF.

External factors such as school rules, teachers, and family background influence SRL and OF. Students have clear goals in future orientation but need self-exploration and commitment to improving OF. Meanwhile, students need to increase their internal motivation in setting long-term goals. The teacher's role as a mentor tries to show the implementation strategy of the SRL process, such as learning strategies and the steps that must be taken to achieve career goals in the future.

\section{REFERENCES}

Ayesha, N. N. (2016). Rancangan Program Intervensi Orientasi Masa Depan dalam Melanjutkan Pendidikan pada Remaja Awal di Desa Mekarmanik Kecamatan Cimenyan Kabupaten Bandung Jawa Barat (Unpublished). Bandung: Universitas Padjadjaran.

BSNP Indonesia. (2009, 06 1). Lampiran Permendikbud Nomor 21 Tahun 2016. Retrieved from BSNP Indonesia: $\quad$ https://bsnp-indonesia.org/wpcontent/uploads/2009/06/Permendikbud_Tahun201 6_Nomor021_Lampiran.pdf

Christensen, L. B., Johnson, R. B., \& Turner, L. A. (2015). Research Methods, Design, and Analysis. Harlow: Pearson Education.

Eldeleklioglu, J. (2012). Assessment of Turkish Adolescents' Future Orientations In Their Life Scripts: A Qualitatife Study. Procedia-Social and Behavioral Sciences, 376 - 381.

Goodwin, C. J. (2010). Research In Psychology: Methods And Design 6th Edition. New Jersey: John Wiley \& Sons.

Havighurst, R. J. (1972). Developmental Tasks and Education. New York: David McKay.

Hoeksema, S. N., Fredrickson, B. L., Loftus, G. R., \& Wagenaar, W. A. (2009). Atkinson \& Hilgard's Introduction to Psychology 15th Edition. Hamshire: Wadsworth Cengage Learning.

Kolesovs, A. (2013). Domain-Specific and General Future Orientation of High School Students in Latvia Under Socioeconomics Change. International Journal of Psychology, 71-83.

Nurmi, J. E. (1991). How Do Adolescents See Their Future? A Review of the Development of Future Orientation and Planning. Developmental Review, 1-59.

Nurshadrina, A. (2017). Gambaran Orientasi Masa Depan Bidang Karir pada Siswa SMA Master Depok (Unpublished). Bandung: Universitas Padjadjaran.

Panadero, E., \& Alonso-Tapia, J. (2014). How Do Students Self-Regulate? Review of Zimmerman's Cyclical Model of Self-Regulated Learning. Anales de Psicologia, 450-462.
Perpusnas. (2019, 11 12). Undang-Undang Republik Indonesia Nomor 20 Tahun 2003 Tentang Sistem Pendidikan Nasional. Retrieved from Pusdiklat Perpusnas: https://pusdiklat.perpusnas.go.id/regulasi/download 16

Ristekdikti. (2019, 02 05). Undang-Undang Republik Indonesia Nomor 12 Tahun 2012 Tentang Pendidikan Tinggi. Retrieved from Lembaga Layanan Pendidikan Tinggi Wilayah VIII: https://ldikti8.ristekdikti.go.id/2019/02/05/undangundang-republik-indonesia-nomor-12-tahun-2012tentang-pendidikan-tinggi/

Santrock, J. W. (2013). Childhood Development 14th Edition. New York: McGraw Hill.

Seginer, R. (2003). Adolescent Future Orientation: An Intergrated Cultural and Ecological Perspective. Online Readings in Psychology and Culture, 6(1). doi: dx.doi.org/10.9707/2307-0919.1056.

Seginer, R. (2009). Future Orientation Developmental and Ecological Perspective. New York: Springer.

Syahputri, N. R. (2017). Peran Self-Regulated Learning terhadap Prestasi Akademik Matematika Siswa SMP di Jatinangor (Unpublished). Bandung: Universitas Padjadjaran.

Wawan, Awalia, S., Nisa, K., \& Hendriani, W. W. (2018). Sekolah Menengah Berasrama. Jakarta: Direktorat Pembinaan SMA.

Zimmerman, B. J. (1989). A Social Cognitive View of SelfRegulated Academic Learning. Journal of Educational Psychology, 329 - 339.

Zimmerman, B. J., \& Moylan, A. R. (2009). Self-Regulation: Where Metacognition And Motivation Intereresect. In J. Dunlosky, \& A. C. Graesser, Handbook of Metacognition In Education (pp. 299 -315). London: Routledge. 